\title{
Teatro y religión
}

\section{TEATRO GRIEGO Y RELIGIÓN}

Reflexionando sobre las relaciones entre la religión y el teatro, se llega a la conclusión de que esas relaciones son históricas. Nada relaciona hoy expresamente al teatro con la religión. Y, sin embargo, de la religión nació el teatro, con toda evidencia: del rito y el mito.

Hoy el teatro lleva una vida más bien mortecina y si se ocupa de temas de religión es igual que como se ocupa de cualesquiera otros temas. Y lo mismo cabe decir de sus derivados, más vitales o al menos más omnipresentes: el cine, el video, la televisión, y hasta el ballet, los espectáculos de revista, sketchs y gags diversos.

Voy a decir algo, pues, sobre la religión en la historia del teatro. Pero es bien evidente que esa historia ha determinado su conformación y pesa hoy, así, en él. Hoy el teatro y sus derivados no están circunscritos a fiestas o lugares sagrados: todos los días son fiesta o todo el año es carnaval, como se quiera. Tratan de temas no míticos sino de todos los días, se visten con el ropaje y el lenguaje de todos los días, no presentan, al menos a primera vista, huellas de unidades rituales o de temas tópicos, míticorituales. Y, por supuesto, salvo excepciones como la ópera, la zarzuela, el ballet, ciertas obras como el Asesinato en la Catedral de Eliot o las tragedias de Lorca, hace tiempo que desaparecieron los coros, la música, la danza. Son excepciones notables, de todos modos.

Aun aparte de ellas, algo queda. La pasión que acaba en sufrimiento y muerte, en la tragedia moderna de nuestro siglo, o el argumento "cómico" del imposible vencido y el final en erotismo o boda, en tantas películas y seriales y novelitas rosa, no son sino la continuación de la antigua tragedia y de la antigua comedia. Y continuación en puntos estrechamente relacionados con el rito y con el mito.

En todo caso, la norma general de tomar un trozo de vida cerrado, ponerle límites, hacerlo coherente e ilustrativo, presentarlo a través de personajes que, por muchos nombres propios que se les ponga, son en realidad tipos genéricos, dar al final, de una manera u otra, una lección al público, todo esto viene del antiguo teatro religioso de base ritual y mítica. Entonces, hablar de los orígenes religiosos del teatro es hacer 
comprensible hasta el más mínimo y trivial derivado final del mismo, por no hablar del verdadero teatro que, a pesar de todo, resurge de cuando en cuando. Para emocionarnos, para ilustrarnos, para dar sentido a nuestras vidas.

Hablemos, pues, de la historia del teatro. Y no se esperará de mí en este lugar, naturalmente, una exposición total y comprensiva ${ }^{1}$. Ni siquiera una exposición de mis ideas sobre los orígenes del teatro griego, del concepto griego del poeta, de la diferencia entre tragedia y comedia: es algo que he hecho en otros lugares ${ }^{2}$ y no me gusta repetirme. Pero recogeré algunas ideas generales sobre el teatro griego, ideas que serán útiles para tratar, luego, el tema de los orígenes del teatro en términos generales.

En Grecia, a partir de un cierto momento, el teatro sufrió un proceso de desformalización y desritualización, de desmitologización también. Lo que luego le ha ocurrido al teatro tiene precedentes en, sobre todo, Eurípides y Menandro: ampliación y fusión de las antiguas unidades rituales, decadencia de los corales, negación del mito, temas y personajes de la vida corriente. En suma, libertad formal y temática, alejamiento de lo sagrado. Aun así, es bien claro que, en términos generales, el teatro griego era todavía un teatro religioso unido a antiguos rituales y a formas tradicionales. Esto se ve por una serie de puntos, entre otros:

1. El teatro tenía lugar en fiestas religiosas y en espacios religiosos, en santuarios de dioses diversos, Dioniso sobre todo. Su transmutación del tiempo y el espacio, su uso de la mímesis con ayuda de la máscara, halla paralelos en varios cultos y en los misterios. El teatro era organizado por la ciudad como tantos otros rituales, impartía como ellos una lección a los ciudadanos.

2. Tiene el teatro griego características sagradas en el vestuario, el lenguaje, los corales, la danza, la música. Quedan en él claras huellas de

1 Remitimos, entre otras obras, a TH. H. GASTER, Thespis (Nueva York, 1951); G. VAN DER LEEW, Vom Heiligem in der Kunst (Gütersloh, 1957); M. BERTHOLD, Weltgeschichte des Theaters (Suttgart, 1968). Para el concepto de lo sagrado y de la fiesta, a R. Calloois, L'homme et le sacré (Paris: Gallimard, 1950) y R. OTTO, Das Heilige, 1917.

2 Cf., entre otros trabajos, "Poeta y poesía en Grecian, en Tres temas de cultura clásica (Madrid: Fundación Universitaria, 1975), pp. 37-67; Fiesta. comedia y tragedia (Madrid: Alianza, 2." ed., 1983); "Aeschylus and the origins of Greek tragedy", Emerita, 53 (1985), pp. 1-14; -Las características generales de la tragedia y comedia griegas", en Curso de teatro Clásico (Teruel: Universidad de Verano de Teruel, 1986), pp. 79-82 (he profundizado luego el tema en varias conferencias todavía inéditas); $\mathrm{El} \mathrm{mito} \mathrm{y} \mathrm{su}$ función en la novela y el teatro antiguo», en J. Monleón (ed.), Mitología clásica y Pensamiento contemporáneo (Mérida, 1987), pp. 1172-178; “Rite, Mythe et Théâtre en Grèce ancienne, en Antbropologie et Théâtre antique (Montpellier, 1987), pp. 37-52. 
unidades sacrales que se encuentran en diversos rituales y en la lírica: corales del tipo del himno, el treno funerario, la canción de boda o de victoria, la súplica, el agón o enfrentamiento (entre coros o coro y actor o actores), la escena de información, la súplica. Y diálogos líricos o epirremáticos entre el coro y los actores.

3. En definitiva, una pieza de teatro griego, sea tragedia o comedia, consiste en un coro que llega cantando ritualmente (párodos) y que se interrumpe varias veces para escenas de actor (con intervención, en el esquema más antiguo, del mismo coro) unidas entre sí por el canto, para concluir con la "Salida" (éxodos) final. En el esquema más antiguo (por ejemplo, en las Suplicantes de Esquilo) el coro es el personaje central y no hay prólogo ni éxodo que no sea coral.

4. El coral inicial presenta una situación de angustia que se resuelve a lo largo de la pieza a través de una serie de cantos y escenas, pero siendo fundamental el agón mencionado. Domina el tema del cambio de manos del poder (nuevo rey o poderoso, expulsión o muerte del antiguo) en un contexto político, también el del enfrentamiento de los sexos. En principio, ese cambio es favorable para la ciudad, significa la renovación de la vida, el alejamiento de los elementos corruptos.

5. Pero lo más característico del teatro griego es que desde el principio esté escindido en tragedia (desde el 534 a.C.) y comedia (desde el 485 a.C.): en un caso dominan el tema del dolor y de la muerte, en otro el del triunfo que trae alegría, abundancia y sexo ( $\sin$ dolor", dice Aristóteles, Poética 1449 b 32). Hay un paralelismo entre los dos géneros, pero también una escisión: en vestimenta, lenguaje, métrica, tema (mito tradicional en tragedia, mito fantástico e inventado en comedia), eliminación de ciertos elementos (los eróticos y burlescos en la tragedia, los dolorosos en la comedia). Los dos "héroes", trágico y cómico, son diferentes. Esta escisión de la vida humana es artificial: cuando se da fuera de Grecia, es por imitación directa o indirecta.

Todo esto ha hecho ver a todos los investigadores que el origen del teatro griego es religioso: ritual y mítico. $\mathrm{Y}$ que el teatro continuaba en Grecia ejerciendo una función religiosa. Era una variante de la lírica; concretamente, de la lírica mimética y dialógica de ciertas fiestas, como ésta era continuación de rituales de pura danza sin palabras o con mínimas palabras: de duelo, expulsión, agón, enfrentamiento violento. Y el poeta del teatro era eso: un poeta o creador, como el de la lírica, un hombre sabio y sagrado, en estrecho contacto con la divinidad, ilustrador de su pueblo. El teatro fue, hasta el triunfo de la filosofía, su rival, la principal fuerza educadora del pueblo. 
Claro que en el detalle de la interpretación puede haber diferencias. Es sabido que Aristóteles vio el origen de tragedia y comedia, respectivamente, en el diálogo solista / coro del ditirambo y de los himnos fálicos, celebraciones dionisíacas ambas. Es sabido que Wilamowitz propuso la idea de un "ditirambo de sátiros" que habría dado origen a la tragedia. Por mi parte, remito a mi libro, arriba citado, sobre el tema.

Mi visión es más amplia: hablo de un preteatro creado, en el caso de la tragedia, seleccionando ciertos rituales de agón y trenéticos (dionisíacos o no), ampliándolos, fundiéndolos al servicio de un esquema biográfico, especializando a un coreuta (en la fase más arcaica) como actor que recita, haciendo que ese coro ampliado o compañía se especialice en mitos dolorosos tomados de la épica y la lírica.

Tespis habría sido el director de una especie de "compañía" traída por Pisístrato, el tirano, para ilustrar su nuevo festival de las Dionisias. Su política era atraerse al pueblo con estas celebraciones comunales y sobrepasar a los festivales de otras ciudades. El avance de Tespis, realmente, fue notable: aun conservando en sus piezas mucho de ritual, desde el momento en que tenía un repertorio rebasó el rito, creó un espectáculo. Y desde el momento en que su actor recitaba, rebasó la lírica. El teatro estaba creado.

En cuanto a la comedia (por no hablar ahora del drama satírico) sería un complemento creado por paralelismo y contraste cincuenta años más tarde para recoger los temas no trágicos de los festivales: temas, ya digo, de erotismo, risa, sátira, triunfo desenfadado.

Renuncio a entrar en el detalle, para el que remito a mis libros. Pero sea cualquiera la posición que se tome sobre puntos concretos, el carácter religioso, mítico y ritual de los dos grandes géneros del teatro griego (incluso de los "mitos" de la comedia, que siguen antiguos esquemas) es aceptado por todos. Incluso en la comedia del siglo IV, que culmina en Menandro y que ya no es política ni colectiva, sino individual y privada, la victoria de los enamorados contra los obstáculos que se les oponen tiene un claro carácter ritual. Pues en los rituales griegos, desde las fiestas de Dioniso a las Oscoforias, las fiestas de Naxos, la expulsión del fármaco y tantos rituales que he ejemplificado, tenemos siempre los mismos motivos: expulsión del dios o el individuo cuyo ciclo ha acabado, tema del nuevo rey y de su victoria, enfrentamiento y conciliación de los sexos, etcétera.

Los grandes temas de las fiestas de primavera, los grandes temas de la vida (enfrentamiento, sexo y renovación, muerte) pasaron de los rituales al teatro. Y la vida misma era ahora puesta en escena por intermedio de pesonajes míticos o de prototipos, en conexión, como queda dicho, con temas colectivos y para enseñanza del pueblo. Claro está, podía 
introducirse un tinte de actualidad exponiendo, a través de esos temas generales y esos caracteres, los problemas actuales de Atenas y su sociedad.

Siendo esto así, resulta extraño que Aristóteles, en su Poética, dedique tan escasa atención al contenido religioso del teatro. Cierto que lo deriva de dos géneros líricos propios de la fiesta. Pero de ahí no pasa: nada dice sobre el papel de la fiesta como lugar fuera del tiempo y el espacio en que todo se transmuta, lugar de libertad para reír y llorar y criticar, para reflexionar sobre la vida humana, para exponer la historia mítica del pueblo: todo ello ya en épica, ya en lírica, ya en teatro.

Todo lo centra Aristóteles en el tema de la mímesis, que nosotros sabemos que tiene que ver, en Grecia y fuera de ella, con esa "imitación" propia de ceremonias y rituales sagrados; pero él nada dice. Su interés es puramente formal y se centra en el tema de la entelequia, de la evolución que lleva a un fin que es la propia naturaleza de la tragedia. Y en la escisión del teatro en los dos géneros de tragedia y comedia. Lo que sí es importante en él es su afirmación (Poética 1451 a 36) de que el teatro no habla de hechos concretos, sino de posibilidades generales, verosímiles. Es la tipificación derivada del mito.

Merece la pena que nos detengamos un momento sobre otro punto. Así como la creación del teatro en Grecia a partir del ritual y a través de la lírica dialógica y mimética es ejemplar, volverá a darse en otros tiempos y lugares, veremos que la consideración moralișta de los dos géneros teatrales por Aristóteles también encontrará paralelos en otras edades: concretamente, en la crítica cristiana de ciertos géneros teatrales.

En realidad, la crítica empezó en Platón, en la República (377 c ss., 597 e ss.), proscribiendo el teatro radicalmente, tanto por su carácter de imitación, de alejamiento del verdadero ser, como por presentar modelos de debilidad moral. Sólo levemente suavizó Platón estas posturas en las Leyes ( 800 d ss.), tras recalcar precisamente el carácter sagrado de las danzas de su nueva ciudad ideal. Aristóteles no insiste en prohibiciones o expulsiones, pero caracteriza positivamente a los autores y temas de la tragedia y negativamente a los de la comedia: los temperamentos serios y nobles van a la primera, sus temas también lo son; y son inferiores los temperamentos de los cómicos y sus temas. Claro antecedente de posiciones cristianas posteriores.

Es notable que el teatro griego sea una especie de ciclo cerrado, al que se añaden a manera de apéndices, eco de su voz que llegará al futuro, los cómicos latinos y Séneca. El círculo que empieza por lo ritual y preteatral, que llega al teatro, que luego desformaliza éste, lo aleja de la religión y de lo colectivo y lo hace algo individual y privado, es recorrido 
plenamente en Grecia, ya lo hemos dicho; y la consideración moralizante del tema del teatro es abierta también aquí, como vemos. Todo esto se repetirá más de una vez.

En parte, son fenómenos paralelos: se parte de unos modelos sociales y religiosos primitivos muy difundidos, hay luego una lógica en la evolución. Pero se inserta un segundo fenómeno: directa o indirectamente el teatro griego ejerce de modelo para hacer pasar de la primera fase a la segunda y la tercera. Así, la historia del teatro arranca varias veces de principios análogos, religiosos; pero hay, además, una línea recta que lo atraviesa y que consiste en el influjo griego, repito que muchas veces indirecto. De Roma a nuestros días ${ }^{3}$.

Otro fenómeno se añade: la escisión griega entre tragedia y comedia comienza a salvarse en Grecia donde, en ciertas obras de Eurípides, hallamos ya elementos "cómicos". Pues bien, el influjo griego ha ido siempre en la dirección de crear o recrear esa escisión. Pero aquí el influjo griego ha sido menos poderoso y por arcaísmo o evolución secundaria hallamos aquí y allá, las más veces, la superación de esa oposición. Y de la oposición de tantos elementos formales y de contenido conexos con ella.

\section{El PRETEATRO EN DIVERSOS LUGARES}

Hablo de preteatro cuando se trata de una representación mimética, normalmente acompanada de danza y de música, en la que intervienen personajes fijos de tipo mítico o histórico. La representación se refiere a un momento de su "biografía": conflicto, lucha, boda, victoria, expulsión o muerte, fundamentalmente, a veces se combinan varios de estos motivos.

Para hablar de preteatro no hace falta que intervenga la palabra: pero es lo más frecuente. Lo antiguo es que el "texto" lo dé la tradición oral, pero puede haber, más tarde, un texto escrito. Lo importante es que se trata de una representación que es siempre la misma y siempre en la misma festividad. Aunque, naturalmente, varía el detalle, pues hay siempre improvisación dentro del modelo tradicional.

Este es el preteatro, que es sustituido por el teatro cuando nos hallamos ante una compañía con un repertorio, así en el caso, en Italia, de la moresca, del bruscello y de la Commedia dell'Arte. Pero hay preteatro en el caso de tal o cual representación de moros y cristianos en tal o cual lugar con motivo de la fiesta de Santiago u otra: desde las más tradicio-

"Véase mi trabajo "Del teatro greco-latino al medieval y moderno", Atlántida, 12 (1991), pp. 416-422. 
nales como la de Trez o la "morisma" de Ainsa, a las más elaboradas en diversos lugares de Levante, donde hay ya, a veces, textos literarios que vienen del siglo pasado ${ }^{4}$. O colóquese, al lado de la Commedia dell'Arte, una versión literaria como es el "Jeu de la Feuillée" de Adam de la Halle, representado en Arras en 1276 y que ponía en escena la boda de Arlequín, un ser demoníaco, y el hada Morgana.

Como se ve, los límites entre el preteatro y las redacciones literarias del mismo no son enteramente claros. Dentro del teatro propiamente dicho, de otra parte, quedan huellas de él, como hemos visto, en Grecia. Igual en la India, tanto en los dramas clásicos como en el Katakali, en la ópera china, en el Noh y el Kabuki japonés, etc.

Por otra parte, nótese que en ocasiones tenemos solamente textos poéticos dialogados entre dos o más personajes. Están próximos al preteatro aunque no han sido nunca representados, probablemente. Así en el caso de textos dialogados de Safo como aquel pasaje en que dialogan Afrodita y sus doncellas ( $140 \mathrm{~V}$.):

- Ha muerto, Citerea, el bello Adonis. ¿Qué haremos?

- Golpeáos, doncellas, el pecho y desgarrad vuestras túnicas.

O, por poner un ejemplo muy distante, en el caso de relatos dialógicos guaraníes 5 .

Lo esencial del preteatro es su carácter ritual, fijo: no hay un repertorio, siempre es lo mismo. Y la repetición de sus caracteres, que pueden cambiar, por otra parte, de lugar a lugar manteniéndose fijos los esquemas formales, los "ritos" mínimos.

Por otra parte, este preteatro refleja un carácter de la fiesta que une elementos serios, dramáticos, con otros "cómicos". La fiesta agraria ofrece de lo uno y de lo otro: ya he dicho que la escisión entre tragedia y comedia es propiamente una innovación griega. La diversión, la risa, la sátira, son tan propias de la fiesta como el rito y mito que nosotros consideramos "Serio" y trágico. Ocurre así que el preteatro se organiza en géneros y subgéneros. Por ejemplo:

1. Piénsese en las representaciones carnavalescas, que ofrecen, de lugar a lugar, infinitas variantes en que intervienen el Carnaval (y en las variantes cristianizadas su oponente la Cuaresma) o la Vieja, o el Peropalo,

4 Cf. por ejemplo las de Caudete, estudiadas por mí en "Los moros y cristianos de Caudete en su contexto histórico y tradicional, Revista de Abenzoares, 1 (1992), pp. 53-63.

5 Cf. L. CAdogan, La Literatura de los Guaranís (México, 1965), p. 99. 
etc., con los temas del triunfo, derrota, juicio, quema, etc. ${ }^{6}$. O en las variantes de las fiestas de las mayas, con mayo o maya (y pueden ser un árbol, un pelele, hombres y mujeres), intervención a veces del motivo de la boda ${ }^{7}$. O en las variantes de la danza de las espadas ${ }^{8}$.

2. Un mismo esquema formal o ritual puede tener "historizaciones" muy varias en diversos lugares; aparte de que los hay de diversos tipos, como de búsqueda, de expulsión, de alternativa de victoria y derrota; lucha de hombres y mujeres con final erótico a veces; etc. Así en el caso del agón o enfrentamiento, por lo demás con esquemas variables.

Para Grecia hemos dado abundante ejemplificación ": aparte de en los rituales, estos agones se reencuentran en la tragedia y la comedia. En la India, un agón de este tipo representaba el de los dioses Kansa y Krisna y sus respectivos partidarios; en el antiguo Egipto, el de los dioses Osiris y Seth y sus partidarios; en Indonesia y otros lugares, el de los demonios raptores de Sita, con Ravana, y los monos sus salvadores, con Rama ${ }^{10}$. En otros lugares, puede tratarse de escoceses y daneses o de ciudadanos de Hatti y de otra ciudad, en la antigua Anatolia, o de dos bandos en la guardia goda de Bizancio. Y recordemos los enfrentamientos de moros y cristianos, derivados de otros anteriores en que el bando tiznado de negro estaba formado por demonios. Las culturas han confluido. Los españoles llevaron estos agones, sin duda, a América, pero allí los había indígenas, también. Entre los indios yaquis, en el estado mejicano de Sonora, con motivo de la Semana Santa, hay el enfrentamiento ritual del bando de Cristo y el de Judas, con varios espisodios y alternativas.

3. Hay otros esquemas que podríamos llamar universales. Así, el del cortejo (a veces en carros) que se detiene para realizar pequeñas representaciones, así en las mascaradas tracias, en las vascas, en el cortejo de los bandereses en los Abruzzos ${ }^{11}$, en los pageants ingleses ${ }^{12}$, etc.

4. Otro esquema muy frecuente es el que hace alternar los motivos trágicos y los de alegría, incluso sátira y burla. Las fiestas agrarias que

- Véase material abundante en J. Caro Baroja, El Carnaval (Madrid: Taurus, 1965), y en Nina EPTON, Spanish Fiestas (London: Cassell, 1968).

Véase el libro de Julio Caro Barola, La estación del amor (Madrid: Taurus, 1979).

* Cf. Marius SCHNeIDeR, La danza de espadas y la tarantela (Barcelona, 1948) (p. 41 y ss. para los elementos miméticos, con personajes fijos).

- Cf. Fiesta.... pp. 404 y ss.

11 Cf. F. W. FUNKE, Crepísculo en Indonesia (Barcelona, 1962), pp. 153 y ss.

11 Sobre todo esto, véase Fiesta..., p. 355.

12 Cf. Heinz KindermanN, Das Theaterpublikum des Mittelalters (Salzburgo: Müller, 1980), pp. 145 y ss. 
impetran y celebran la nueva vida, las fiestas de que viene, entre tantas cosas, el teatro, están llenas, junto a momentos solemnes y aun trágicos, de otros satíricos, bufonescos, puramente vitales: danzas animales o con zancos, alegría del enos o de la victoria. Así en la Grecia antigua, así en todo el mundo.

No es, pues, extraña esa alternancia de los dos temas: en las Oscoforias de Atenas tras el llanto por la muerte de Egeo viene la alegre proclamación de Teseo y hay alternancias parecidas en las fiestas de Dioniso en Naxos o de Jacinto en Esparta, en las de Attis en Roma, en los triunfos romanos. Así, en la Edad Media, en las intervenciones de juglares y trovadores o en los Festnachtspiele de Alemania ${ }^{13}$. En España, en las intervenciones jocosas, en las funciones de Iglesia, de enmascarados y de sátiras diversas, que prohibían ya los Concilios de Toledo y las Partidas. Y en diversiones semejantes en el Corpus, en las representacions de comedias y en las de los Autos Sacramentales ${ }^{14}$. Y en los pasos y entremeses de nuestro teatro desde el siglo $\mathrm{XV}$, en las mascaradas vascas, en tantos festejos carnavalescos. Otras veces el elemento "cómico" se enquista, por así decirlo, en el "serio": caso del bufón en el teatro indio, del "gracioso" en nuestro teatro clásico, de elementos del mismo tipo en Shakespeare.

Había, pues, en los festivales y en el preteatro motivos que ofrecían la posibilidad de la escisión tragedia/comedia, que hacen ver que este "invento" griego tiene raíces generales, como también las tiene la fusión de ambos géneros. Aquí o allá han surgido pequeñas farsas puramente cómicas, como las laconias y las megáricas en Grecia, como esos intermedios de que hablamos en diversos festivales, a saber, los pasos, entremeses, sainetes.

Después de esto, convendría contestar brevemente a una pregunta: ¿Dónde surgió, dónde está documentado el preteatro? Podríamos responder: en todas las sociedades agrarias que celebran estas fiestas. Está en ellas mezclado con elementos no miméticos, orales o no, muy diversos. Lo que ha hecho el teatro es elegir, combinar, sintetizar, dar nuevo sentido; y crear piezas y piezas con una nueva originalidad.

Prescindiendo de los ejemplos ya dados, en Frazer y los etnólogos en general pueden espigarse toda clase de datos, en mi Fiesta... he dado ejemplos numerosos: de España, de Europa en general, del mundo

13 Cf. KindeRmanN, op. cit.. pp. 74 y ss., 120 y ss., 168.

14 Para las comedias, con sus aditamentos o entreactos de loas, entremeses, jácaras, bailes, mojigangas, véase José DELEITO Y PIÑUELA, También se divierte el pueblo (Madrid: Espasa Calpe, 1966), pp. 198 y ss.; para los Autos, René Andioc, Teatro y Sociedad en el Madrid del siglo XVII (Madrid, 1976), p. 354 y ss. 
extraeuropeo ${ }^{15}$. Recuerdo la boda sagrada en Sumeria y Babilonia y la ceremonia de la coronación egipcia, en que el nuevo Faraón hacía el papel de Osiris ${ }^{16}$; los misterios de Eleusis, en que los mistas eran los compañeros de Deméter en su búsqueda de la hija, en que se personificaban personajes como la obscena vieja Baubó.

Pero quizá sea mejor, para destacar la universalidad, presentar algunos ejemplos de América. Por ejemplo, los poemas dramáticos aztecas, danzados ${ }^{17}$ : la "Embajada de Huexotzinco", el "Bailete de Nezahualcóyotl", el "Bailete a la muerte de Tlacahuepan". Intervienen mensajeros, Motecuzoma, poetas disfrazados de aves, un coro. Y había un teatro maya que en edificios especiales escenificaba con ayuda de la danza mitos dialogados. Nos queda el drama llamado "Rabinal Achí, de influencia ya hispánica ${ }^{18}$. Pero quizá sean más interesantes, porque podemos presenciarlas hoy todavía, las danzas rituales del candomblé y el umbanda, en el Brasil ${ }^{19}$. Son danzas frenéticas que acompañan a las ceremonias de culto de las religiones de componente africano. Los danzantes cantan en honor de los orixás o dioses: salutaciones, plegarias, mitos. Y los orixás se aparecen, "montan" a los danzantes, éstos "Son" ya ellos. Los orixás reciben sus atributos, danzan.

Por supuesto, podrían ponerse ejemplos casi infinitos, podríamos ahondar en el detalle descriptivo. No creo que sea necesario en este contexto. Lo que nos interesa es la relación de todo este complejo que va por transiciones de la danza y la lírica dialógica al preteatro, al teatro, con infinitas variantes, con todo lo que llamamos religioso.

Prescindamos del Cristianismo, de que hablaremos a continuación: trae consigo un concepto de lo religioso que es particular, lo coloca en una relación especial con el preteatro popular y con el teatro greco-latino. La

15 Me gustaría anadir, para el Pais Vasco, Luis MichelenA, Historia de la Literatura Vasca (Madrid, 1960), pp. 26 y ss.

16. Véanse más detalles sobre estas y otras fiestas egipcias en M. BOuISsON, La Magia (Barcelona: Luis de Caralt, 1962), pp. 61 y ss.

$r^{-}$Cf. Angel M. GaRibay K., La Literatura de los Aztecas (México: Joaquín Mortiz, 1962), pp. 79 y ss.

18 Cf. Pedro CorreA, La cultura literaria de los mayas (Granada, 1991), pp. 115 y ss.

19 Véase, entre otra bibliografía: José Ribeiro, Magia do Camdomblé (Río de Janeiro, 1985); Edison CARneiro, Candomblés da Babia (Río de Janeiro, 1986); Xangó Inbançâ (São Paulo, 1987); Oliveira MAGNO, Antigas canções da Umbanda (Río de Janeiro, s.a.); Pontos cantados e riscados (Río de Janeiro, s.a.); José PaIva de OLIVEIRA, Cerimonia do Candomblé praticado no Brasil, y O ritual na Umbanda e no Candomblé (Rio de Janeiro, s.a.). 
sociedad cristiana fue, de todos modos, permeada por el antiguo espíritu de la fiesta, más antiguo, espíritu que es la raíz del teatro.

De esta fiesta hablamos y de las ideas que en ella se expresan estamos hablando cuando hablamos de religión y teatro. Aunque esa fiesta esté hoy en decadencia, porque hoy la fiesta penetra toda la vida y tiene, por ello, menos significado. Aunque el teatro esté en decadencia porque ha engendrado hijos demasiado poderosos. A pesar de todo, mucho queda.

El preteatro y el teatro han significado un momento de descanso del tiempo, del espacio, de las constricciones sociales; un momento de reflexión, de libre dolor, de libre sátira y risa. En la fiesta todo cambia: el vestido, las comidas, los comportamientos. Hay una comunidad humana, hay una libertad interior. La historia del pueblo se refleja en sus mitos -narrados, danzados, representados-. No hay fronteras claras entre lo sagrado y lo profano, el dolor y la alegría, lo comunal y lo individual, los hombres y las mujeres, los hombres y los animales, incluso. Los dioses y las almas de los muertos pueden circular entre los vivos. Los sacerdotes, los danzantes, los poetas pueden unir entre sí todos esos mundos. La máscara y el disfraz ayudan a todo esto, también el alcohol, la danza, la música, pero no son estrictamente necesarios. Es otro mundo: el mundo del caos original que todo lo hace posible. Por un momento, la vida se detiene entre el pasado y el futuro, para propiciar el salto del primero al segundo.

Las religiones agrarias hacían posible todo esto. Los dioses podían traer la abundancia y la felicidad, también la sequía, las catástrofes naturales, la muerte. Algunos estaban, al cabo del año, muertos o gastados: había que cambiarlos por otros o que hacerlos nacer o venir de nuevo o, al menos, que renovar su vitalidad mediante ceremonias. Había que propiciarlos.

La vida era y es peligrosa. Tiene momentos decisivos -el nacimiento, la lucha, la boda, la muerte- en los que se precisa ayuda y en los que se puede errar. Son momentos sagrados que se enriquecen con la ayuda del rito y del mito: con la ayuda divina. Porque también los dioses y los héroes del pueblo, que ahora son presentados en la épica, la lírica, la danza, el preteatro, pasaron por esos trances. Sus vidas, sus comportamientos, sus sucesos, son ejemplares, ayudan.

Tenemos que despojarnos del concepto de religión que el Cristianismo ha difundido: conserva cosas de las antiguas religiones, pero elimina y añade. Mira o miraba al teatro con desconfianza. Y tenemos que despojarnos del antiguo moralismo que nos viene de los filósofos griegos, tan poco amigos, en definitiva, del teatro. La fiesta y la danza son "trabajo", pues propician el éxito de éste, la cosecha, la abundancia. La risa y la 
sátira son tan sagradas como el dolor: es cosa de la religión el dar salida a todo esto. Es sagrado el sexo: el sexo libre de las coerciones institucionales, aunque sea por un día. Pero el que una cosa sea sagrada en este sentido, no quiere decir que no sea cosa, al tiempo, de diversión y risa. Los dioses, los muertos, los animales no están distantes: están ahí para ayudarnos, instruirnos, para que, al tiempo, se ponga en conexión con ellos la historia del pueblo, la vida toda.

Volvamos al preteatro, continuador de la danza y la lírica, y al teatro. La fiesta agraria, con la presencia de dioses, muertos y animales divinizados, explica que lo central en estos ritos sean siempre los grandes temas de la vida humana, sus momentos de inflexión. Ya están mencionados. Hay la subida y el enfrentamiento y la caída, hay el juicio y la condena, hay el sexo, hay el nacimiento y la muerte, hay la búsqueda de respuestas, del modelo divino o heroico o tradicional, en todo caso. $\mathrm{Y}$ las preguntas que el hombre se hace a sí mismo.

De la fiesta ha nacido toda la literatura, toda la cultura humana, diríamos: música y gimnasia decían los griegos. Volviendo a lo que nos interesa, la fiesta explica que el preteatro y el teatro presenten y expliquen esa vida humana por ejemplos que son tipos fijos: dioses, héroes, hipóstasis. No interesa el personaje individual, la vida individual, los problemas puramente privados; sólo los biológicos, diríamos, y los sociales o políticos. No interesan las formas libres en el vestido, lenguaje, música, unidades literarias: la máscara tipifica, ello ocurre incluso sin máscara, se trata de personajes "de siempre". Y los esquemas formales son tradicionales, derivados del rito. Con ello los participantes en la fiesta, que no espectadores, están cómodos, no se ven arrastrados a nuevas incertidumbres.

Cierto, los griegos, que partieron de aquí, avanzaron ya en el sentido de la desformalización, de la innovación, de la modernidad, de lo privado, de la incertidumbre. Y el nuevo teatro y los géneros de él derivados, no han hecho sino repetir su ciclo, llevarlo más allá. Ya lo dijimos al comienzo.

Pero todo esto es secundario. A pesar de todo, son los temas centrales de la vida los que siguen siendo antes que nada explorados, aunque sea en un mundo sin dioses, sin héroes antiguos, casi sin modelos. A pesar de todo, y esto ya lo vio Aristóteles, son situaciones generales, tipos generales los que dominan el teatro. Todo esto es herencia de la fiesta agraria, del preteatro. Luego, el teatro de los griegos y el romano, derivado de los griegos y transmisor de los mismos temas hasta que fueron redescubiertos, no hicieron sino insistir en ellos, darles énfasis, calidad literaria, matiz de pensamiento. 


\section{CRISTIANISMO, PRETEATRO Y TEATRO}

El Cristianismo nació en un pueblo que no tenía experiencia del teatro, si no era a través de los griegos y romanos, que lo sojuzgaron. Llegó un momento en que la tragedia, que ponía en escena dioses y héroes paganos, era poco más que un recuerdo; y también la comedia, por lo demás convertida, en sus últimas fases, en una exposición de temas privados, de bodas sobre todo, que no podían interesar mucho a los cristianos.

El ambiente de la fiesta antigua, que daba un descanso a los hombres y buscaba el favor divino en beneficio de la vida y las cosechas del año venidero, difería, también, bastante del que los cristianos propiciaban. "Mi reino no es de este mundo", dijo Jesús, y también aquello sobre los pájaros del cielo, a los que Dios da de comer, y sobre los lirios del campo, a los que viste bellamente, sin esforzarse ellos. Por otra parte, la visión moralista del Cristianismo desaprobaba los géneros que realmente estaban vivos: el mimo y la pantomima.

Cierto que una religión más popular reconoció, poco a poco, a algunos santos como patronos de las más inmediatas necesidades humanas. Y que los hombres más ilustrados del Cristianismo no dejaron de reconocer la deuda de todos para con el pensamiento y la literatura, incluido el téatro, de la antigua Grecia. Así se creó una situación difícil y ambigua: las grandes religiones monoteístas, no sólo el Cristianismo, son en principio ajenas al teatro. Pero el Cristianismo (y luego las otras religiones) ha sido permeado por ese teatro, nacido de rituales agrarios del mundo politeísta, y fecundado por el pensamiento griego. Pero siempre difícilmente. Retracemos algunos rasgos de esta historia.

En principio, hubo una oposición frontal a lo que quedaba del teatro. La habría habido igualmente, sin duda, frente a la tragedia, que presentaba el espectáculo del dolor humano, que el Cristianismo quería curar con la esperanza de la otra vida; pero la tragedia ya no existía. La habría habido frente a la comedia aristofánica (no comprendida, en realidad, hasta el siglo XIX) e incluso frente a su continuadora, pero ya no existían. La oposición fue, principalmente, frente al mimo y frente a todos los restos de las festividades populares.

Así ya en Tertuliano, así en el canon del III concilio de Toledo (589 d.C.) que dice que debe exterminarse la costumbre de los bailes y los cantos en las Iglesias. Así en las Partidas (I, tít. VI, 34) que estatuyen que los sacerdotes no deben representar farsas burlescas en las Iglesias, ni permitirlas dentro, ni asistir a las que hagan otros. Durante mucho tiempo hubo una gran desconfianza respecto al teatro: recuérdese que no se permitió enterrar a Molière en sagrado, recuérdese la prohibición de re- 
presentaciones de teatro en Madrid a la muerte de Felipe III y luego de 1646 a 1649.

En Bizancio, el escrito de Eustacio de Tesalónica Peri bypokríseos es un ataque contra el milmo (ciertamente, a veces anticristiano). Pero, pese a todo, la herencia de los antiguos mimos e histriones siguió viva en Bizancio, siguió viva en Occidente a través de los juglares y los trovadores: ayudó a la creación de un nuevo teatro. Incluso de un teatro cristiano. De otra parte, subsistía un modelo. En Bizancio, se sabía del antiguo teatro griego. En Occidente, a través de Terencio, luego de Séneca y Plauto, se sabía de la existencia del teatro sin más, incluso esto fue suficiente. Y junto a la hostilidad cristiana al teatro fue surgiendo un nuevo teatro cristiano, que dramatizaba pasajes del Evangelio y las Antífonas: y ello tanto en Bizancio como en Occidente. El conocimiento de la existencia del teatro antiguo fue, pienso, decisivo ${ }^{20}$.

No es cuestión de repasar aquí en detalle esta historia, en realidad bien conocida. Quiero referirme a los llamados tropos, de los cuales los más antiguos en Castilla son unos de Silos del siglo $\mathrm{xI}$ : los hay, sobre todo, en relación con la visita de los pastores y con la Resurrección de Cristo. Ya en el siglo $x$ hay en Saint Gall, Suiza, un drama relativo a la visita de las tres Marias a la tumba de Cristo; y para finales del mismo hay noticia de representaciones en Santa Sofía, en Constantinopla.

De ahí deriva nuestro Auto de los Reyes Magos, del siglo xiI, y otra literatura posterior. $\mathrm{Y}$ hay luego y sobre todo los misterios, originales de Francia pero extendidos también por tierras de Cataluña y Aragón y que eran un verdadero teatro que congregaba multitudes; las sacre representazioni en Italia; etc. Todavía se han conservado representaciones de la pasión en Oberammergau, en Olot, etc.

Pero en la Edad Media y en nuestro Siglo de Oro las piezas religiosas eran acompañadas, como se ha dicho, de intermedios de representaciones profanas, desde los Festnachtspiele a los entremeses, mojigangas, etc. El teatro cristiano intentaba llevar al pueblo el drama evangélico, ni más ni menos que los pasos de las procesiones y que la escultura de las catedrales. Drama que, a veces, admitía episodios cómicos en relación con la traición de Pedro o con José, por ejemplo; o bien, ya se ha dicho, acompañamientos profanos. Ya desde época visigótica tenemos noticia de estas represen-

20 Véase, entre otra bibliografía: R. B. Donovan, The liturgical Drama in medieval Spain (Toronto, 1958); G. COHEN, Le théâtre en France au Moyen Age: I. Le théâtre religieux (Paris, 1928); Fernando LÁZARO, Teatro Medieval (Madrid, 1970); y el libro ya citado de Kindermann y abundante bibliografía que aduce. 
taciones y del problema que creaban ${ }^{21}$. Después de todo, esto no era sino un volver a nacer de lo que sucedió en la Grecia antigua, donde a la tragedia seguía el drama satírico y en las mismas festividades se representaba también la comedia. Todavía en el siglo XviII había representaciones sobre el tema de los magos en la catedral de Toledo. Pero el teatro acabó por ser expulsado de las Iglesias, ya antes hemos dado datos sobre esto.

O sea: la Iglesia temía al teatro, que creaba un ambiente de expectación y fiesta y tendía a introducir motivos profanos. A reconstruir la unidad de la vida humana, como en Grecia y Roma, donde diversos géneros acompañaban a la tragedia y aun tendían a fundirse con ella. Pero la Iglesia aprovechaba, al tiempo, el poder del teatro sobre el pueblo para visualizar, hacer sentir profundamente todos los dramas de la vida, a partir de la vida de Cristo: nacimiento, reconocimiento glorioso, pasión, muerte. De una manera diferente, que quería ser selectiva y que todo lo organizaba en torno a la vida de Cristo, las antiguas fuerzas movidas por el teatro para visualizar y hacer sentir los momentos primordiales de la vida humana, continuaban actuantes. Lo hacían a través de una dramatización de la vida de Cristo que era íntimamente vivida. De aquí vino, en España, la tradición de los Autos Sacramentales, que ampliaron su contenido original e introdujeron elementos del mito antiguo, de la magia y de la antigua filosofía: el tema de El gran Teatro del Mundo, por ejemplo, es un tema cínico. Se trataba de captar al público con efectos llamativos, con la introducción de entremeses, etc. Se lograba a medias: contra los sainetes vino la crítica no sólo de los ilustrados, también del catolicismo más severo. Los Autos fueron prohibidos en $1776^{22}$.

En suma, el teatro propiamente cristiano competía con dificultad con el concepto más amplio del teatro procedente ya de la Antigüedad, ya del ambiente popular, digamos folklórico o carnavalesco. Lo mismo ocurrió con el teatro más propiamente "serion, de Universidades y Academias y, sobre todo, de los Jesuitas, que lo utilizaron también muy ampliamente para la evangelización de América. Fue allí muy importante en Brasil, Perú, Argentina, Bolivia, Paraguay, Chile en los siglos XVI y XVII; en nuestras Universidades, hasta el XVIII ${ }^{23}$.

21 C. KindermanN, op. cit., p. 231.

22 Sobre todo esto, cf. René ANDIOC, op. cit., pp. 345 y ss. Un autor contemporáneo escribe: «en estos (entremés y sainete) hallan únicamente diversión y la pieza principal les es fastidiosa... quisiera ver yo representado un Auto en que no hubiese sainetes, músicas, galas ni decoraciones. Estoy seguro de que irian más baratos los asientos".

23 Para el primero, cf. el artículo .Theater. de la Enciclopedia Británica, vol. 18, p. 224; para el segundo, Alfredo HERMENEGILDO, Los trágicos españoles del siglo XVt (Madrid, 1961), pp. 118 y ss. 
En realidad, este teatro continuaba el ensayo hecho por la monja Hrosvita, en el s. $\mathrm{x}$, cuando escribió comedias cristianas inspiradas en Terencio.

El teatro jesuítico era, al tiempo, estrictamente "serio" y cristiano y muy inspirado por la tradición del teatro antiguo. Pero no logró trascender los estrechos límites catequísticos y académicos, ni conectó con el verdadero sentir del pueblo. El espíritu del teatro antiguo continuó operante en cierta medida: en la medida en que el nuevo teatro cristiano hacía vivir, como digo, los momentos esenciales, dramáticos de la existencia a través de un modelo al tiempo remoto y presente, la vida de Cristo. Pero era un modelo muy concreto, único, que quedó como una vía del teatro secundaria y cerrada, ajena a la principal.

La línea principal del teatro es la que hace evolucionar las formas populares occidentales, derivadas de un preteatro más o menos semejante al griego, bajo el influjo del modelo greco-latino. A veces, ciertamente, ese preteatro popular hacía conexión con el cristiano: en la moresca que enfrentaba a moros y cristianos, en el tema del Carnaval y la Cuaresma, en versiones cristianizadas del tema del mayo y otros. Esa fusión de lo popular y lo cristiano está viva en muchas fiestas populares de hoy día, en representaciones como la de los indios yaquis arriba aludida, en festejos del Corpus, hasta en la inclusión de elementos populares diversos en las Comedias y Autos. La danza, el agón, la boda se recuperaban así para el teatro.

Pero tampoco fue esta la vía esencial. Esta la encontramos, por ejemplo, cuando Torres Naharro redescubre el concepto de la comedia y el autor de La Celestina crea el de la tragicomedia, cuando la tragedia vuelve a la vida en obras de Lope o Calderón o Shakespeare; y siempre a través de prototipos ejemplares, sean del mito antiguo, sean de la historia griega o romana, o judía o medieval. Los grandes temas del antiguo teatro son descubiertos de nuevo. Y no quiero insistir aquí en su explotación en el teatro posterior ${ }^{24}$; sea por simple coincidencia en el descubrimiento de lo que es simplemente humano, sea por influjo directo. Sólo quiero llamar la atención sobre mi estudio de este tema en García Lorca ${ }^{25}$.

Me da la impresión de que esa confluencia de los géneros populares medievales con los antiguos, conocidos gradualmente a través de Terencio, Plauto y Séneca, no ha sido suficientemente apreciada. En definitiva, la

24 Digo algunas cosas en mis Raíces griegas de la cultura moderna (en colaboración) (Madrid, 2." ed., 1994), pp. 329 y ss.; y en el trabajo ya citado «Del teatro greco-latino al medieval y modernon.

25 Cf. "Las tragedias de García Lorca y los Griegos", Estudios Clásicos, 96 (1989), pp. 51-61. 
tradicion preteatral de nuestros pueblos fue absorbida por el teatro de raíz griega, ni más ni menos que la tradición preteatral romana e itálica fue absorbida por la griega. El teatro griego encontró así, a lo largo de tres etapas, una continuación. Los nuevos teatros son, desde un cierto punto de vista, ciclos nuevos; desde otro, continuación de los griegos. Y en ello se repiten, ya lo dije, fenómenos a los que los griegos se anticiparon: desformalización, fusión de géneros, temas privados, etc. En cambio, algunos preteatros que no recibieron el influjo griego crearon teatros como los de la India, la China y el Japón antes aludidos, pero éstos quedaron, en cierto modo, en vías muertas y tradicionales. La novedad, la creación de algo nuevo, fue cosa de los griegos y de sus herederos: nosotros.

No pasaron de ese nivel "detenido" algunas piezas derivadas del teatro medieval, como son ciertas morescas, la Mummer's Play inglesa, el Ludus de rege et regina, b Commedia dell'Arte. Representan, en definitiva, vías muertas, caminos cerrados. La fecundación, el cruce, llegó cuando en bodas principescas de Italia, como las de Alfonso d'Este en Ferrara en torno al 1500 , se representaban alternativamente Plauto y la moresca. O cuando Juan del Enzina producía obras ya de tipo tradicional carnavalesco (la Égloga de Antruejo), ya de tipo clásico (égloga de Plácida y Victoriano), ya de tipo religioso (autos del Nacimiento y de la Pasión). Igual en Gil Vicente, en Torres Naharro, etc.

Lo esencial es que llegó a redescubrirse la esencia del teatro, de la comedia, de la tragedia. Que los temas heroicos o burgueses griegos fueron doblados, primero en España e Inglaterra, luego en Francia, por otros diversos, pero siempre con los mismos principios. A saber, destacar los temas dolorosos o alegres de la existencia humana a través de modelos genéricos y en un ambiente de fiesta: rotura de la normalidad, reflexión, dolor, diversión. Es esto lo importante, no la adhesión o no a las famosas tres unidades, que tampoco seguían los griegos. Esta es la línea que triunfó, no las otras alternativas o sincréticas. La nueva cultura que surgía desde finales de la Edad Media halló una de sus expresiones más notables en el teatro. En un teatro que era, a la vez, autóctono y greco-latino. Esta es la verdadera línea del teatro: lo demás son intentos más o menos logrados, pero que han acabado en repetición y manierismo y tienen una riqueza infinitamente menor.

\section{SÍNTESIS SOBRE RELIGIÓN Y TEATRO}

Pero esta línea ha llevado, paradójicamente, como al comienzo dije, a la separación de teatro y religión. Digamos algo de esto. 
Lo primero: la religión del teatro no es, en principio, la religión cristiana, que tiene con él una conexión muy limiitada. Viene de un estadio de religión popular, naturalista, centrada en el tema de la vida en sus momentos esenciales. Una religión que difícilmente admitía la distinción entre lo sagrado y lo profano, lo doloroso y lo risible, que eran ajena al moralismo que divide a los hombres en buenos y malos, que separa a Dios del demonio. Esa religión es cosa del pasado, y más en nuestro ambiente urbano y tecnificado. Lo que de ella quede en el teatro y en nuestra vida toda hemos de descubrirlo mediante el análisis, no está a la vista.

Ciertamente, cuando esa religión produjo el teatro, éste pudo ir creando un nuevo pensamiento, una nueva reflexión; y pudo absorber el pensamiento de otros orígenes. Así, el pensamiento filosófico de los griegos clásicos, el pensamiento estoico, el pensamiento cristiano, ciertas vetas del pensamiento de los románticos o los existencialistas. El teatro pudo, así, concretarse de varias maneras, crear, diríamos, diferentes géneros y productos: profundizando de varios modos en el núcleo de los problemas humanos, limitando también sus temas e intereses, su visión de la vida.

El teatro, así como los géneros de él derivados, lo que hace es ofrecer modelos humanos en acción, en conflicto, para presentar a los oídos, la vista y el entendimiento qué es lo que de ahí resulta. Tiene que esquematizar: ni una acción ni una palabra son inútiles, todo encaja. Y no hay conclusión fija: puede ser religiosa desde nuestro punto de vista actual ( sólo Dios, Marco", en Panorama desde el Puente, de Miller) o pedir, tan sólo, un olvido, un descanso, así en Bodas de sangre, de García Lorca. O hay una simple presentación dramática de "cómo son" las cosas, la vida. O mil posiciones más.

El buen teatro no es teatro de tesis. Hace ver simplemente, hace sentir, hace pensar. ¿Es religioso? Si lo es, es en el sentido de esa antigua religión simplemente naturalista, humana, de que hemos hablado y que convive de varios modos o no convive con la cristiana, que persiste a veces ocultamente, pero que ya no vemos como religión. El Cristianismo puede aparecer como un segundo componente, como pueden aparecer otros componentes. Y la antigua religión que dio origen al teatro y que convivió pese a todo durante mucho tiempo con el Cristianismo, podemos hoy considerarla disuelta en nuestras vivencias todas, hasta hacerse casi irreconocible como tal religión. Salvo en ambientes populares y agrarios en que el preteatro sigue hasta cierto punto vivo.

En todo caso, podemos hablar de religión, en relación con el teatro en general y no ya con tal o cual pieza, en el sentido en que abstrae, generaliza, presenta modelos, advierte. En realidad, lo mismo hace la novela o ciertas novelas, aunque los medios expresivos sean diferentes. 
Nacido de las antiguas religiones, el teatro las ha disuelto en la vida de todos los días, ésta les ha señalado límites, las ha despojado de antiguos rasgos que hoy nos son ya ajenos.

Pero, a pesar de todo, el teatro supera a la vida de todos los días, sigue ofreciendo una serie de situaciones, de posibilidades, de esquemas generales que quizá algún día afecten personalmente al espectador. Las antiguas religiones crearon estos esquemas; el teatro, en cierto modo, los conserva para nosotros.

\section{FRANCISCO RODRÍGUEZ ADRADOS \\ Real Academia Española}

Nacido de las antiguas religiones naturalistas y mágicas, el teatro las ha disuelto en la vida de todos los días; pero conserva, pese a todo, los grandes temas de la vida humana que aquellas presentaban miméticamente. El trabajo estudia los distintos "preteatros" surgidos sucesivamente en ese ambiente y su conversión en teatro cuando fueron penetrados una y otra vez por los esquemas teatrales griegos. Y la difícil lucha del teatro con el Cristianismo y su evolución dentro de la vida moderna.

The theatre, born from the naturalist and magical ancient religions, has melted them in everyday life, but still keeping, despite everything, the great themes of the human life, which the religions offered only on a mimetic way. This paper studies the various "pre-theatres" arisen in those atmospheres and their transformation in theatre when they were imbued with the Greek theatrical ideas once and again. It also studies the conflict between the theatre and the Christianism as well as their mutual relationship and the development of the theatre within the modern life. 